\title{
Gambaran Perundungan pada Siswa Tingkat SMA di Indonesia
}

\section{Potrayal of Bullying among High School Students in Indonesia}

\author{
Grista N. A. Damanik, Ratna Djuwita \\ Fakultas Psikologi Universitas Indonesia \\ Email:nandy.damanik@gmail.com; juwita@ui.ac.id
}

$\begin{array}{ll}\text { KATA KUNCI } & \text { Indonesia, mahasiswa, perundungan, siswa, SMA } \\ \text { KEYWORDS } & \text { Indonesia, college student, bullying, student, high school }\end{array}$

ABSTRAK Penelitian ini ditujukan untuk memetakan kejadian dan perilaku perundungan pada siswa tingkat SMA di Indonesia. Partisipan dalam penelitian ini adalah 138 mahasiswa tingkat pertama yang bersasal dari SMA di Indonesia, yang diminta mengingat dan menceritakan kembali pengalamannya terkait perundungan semasa SMA. Hasil analisis deskriptif menunjukkan perundungan terjadi pada $75,8 \%$ sekolah dari partisipan. Sebagian besar perundungan berbentuk verbal (35,1\%), terjadi di dalam kelas (63,1\%), dan pada jam istirahat (64,5\%). Partisipan yang pernah menjadi pelaku $(18,8 \%)$ menyalahkan perilaku aneh korban sebagai penyebab utama perundungan. Dari 34,1\% partisipan yang pernah menjadi korban, sebagian besar memilih untuk mengabaikan kejadian. Sementara dari 69,6\% partisipan yang pernah menjadi saksi perundungan, sebagian besar memilih untuk tidak melakukan apa-apa karena tidak ingin terlibat. Meskipun perundungan terbukti terjadi di sekolah, keseluruhan partisipan memiliki persepsi positif terhadap sekolah. Meski demikian, hasil uji t-test menunjukkan persepsi yang lebih baik mengenai sekolah pada partisipan yang belum pernah menjadi korban, saksi, maupun pelaku dibandingkan partisipan yang pernah.

ABSTRACT This study was aimed to identify the bullying incident and behavior among Indonesian high school students. The participants of this study were 138 first year college students previously studied in Indonesian high school, who were asked to recall and retell their experiences regarding bullying in school. The descriptive statistical analysis of the data showed that bullying happened at $75.8 \%$ of the schools. Most bullying incidents happened in the form of verbal bullying (35.1\%), inside the classrooms (63.1\%), and at lunch break (64.5\%). Participants who had been a bully (18.8\%) mostly blamed the victim's odd behavior as the reason for bullying. Out of $34.1 \%$ participants who had been a victim, a majority had chosen to 
ignore the bullying incidents. Out of $69.6 \%$ participants who had witnessed bullying incidents, a majority had chosen to be uninvolved. Even though bullying was proven to take place at school, a majority of the participants had positive perception towards their school. However, results from t-test analysis showed better perceptions toward school in participants who had never been a victim, a witness, or a bully, compared to participants who had.

\section{PENDAHULUAN}

Perundungan (bullying) merupakan salah satu masalah yang sering terjadi di sekolah di berbagai negara (Craig dkk., 2009; Smith, Cowie, Olafsson, \& Liefooghe, 2002) dan memiliki dampak negatif terhadap korban (Hernández \& Seem, 2004; Juvonen, Yueyan, \& Espinoza, 2011), pelaku (Wolke, Copeland, Angold, \& Costello, 2013; Gastic, 2008; Morrison, 2002), maupun siswa-siswa lain yang menjadi saksi dari kejadian perundungan (Pečjak \& Pirc, 2017; Cowie, 2014; Thornberg, Tenenbaum, Varjas, Meyers, Jungert \& Vanegas, 2012; Tsang, Hui \& Law, 2011).

Pelaku cenderung mengalami masalah kesehatan, kesejahteraan, dan hubungan antar pribadi (Wolke, Copeland, Angold, \& Costello, 2013). Korban yang ketakutan menjadi sering membolos sehingga mempengaruhi prestasi akademik, mengalami kesulitan dalam berteman dengan siswa lain dan seringkali dijauhi siswa lain karena khawatir akan terikut menjadi korban (Hernández \& Seem, 2004; Juvonen, Yueyan, \& Espinoza, 2011). Sementara siswa yang menyaksikan perundungan dapat mengalami gangguan konsentrasi belajar (Vanderbilt \& Augustyn, 2010) yang disebabkan rasa kuatir akan menjadi korban berikutnya (Cowie, 2014; Thornberg dkk., 2012; Tsang, Hui \& Law, 2011). Secara umum dapat dikatakan bahwa perundungan di sekolah mengakibatkan hambatan yang signifikan terhadap perkembangan anak, baik secara kesehatan fisik (Gini \& Pozzoli, 2009) maupun pembentukan psikologisnya
(Hawker \& Boulton, 2000). Oleh karena itu perundungan menjadi salah satu permasalahan yang telah diteliti secara meluas dan mendalam di berbagai negara.

Dari studi literatur diketahui bahwa faktor budaya juga berperan dalam kejadian perundungan di sekolah (Lai, Ye, \& Chang, 2008; Kanetsuna, Smith, \& Morita, 2006). Beberapa penelitian berusaha membandingkan karakteristik perundungan di beberapa negara dengan sistem sosial dan budaya yang berbeda untuk meningkatkan pemahaman mengenai gambaran dan faktor-faktor yang mempengaruhi perundungan yang terjadi di sekolah. Penelitian mengenai karakteristik perundungan di kawasan Asia Pasifik (Lai, Ye, \& Chang, 2008) menunjukkan perbedaan sikap dan persepsi siswa yang pernah mengalami perundungan terhadap sekolah di negara-negara yang diteliti. Dari penelitian Kanetsuna, Smith, dan Morita (2006) diketahui bahwa intervensi perundungan berbasis sekolah sesuai untuk diterapkan pada siswa Inggris, sedangkan pada siswa Jepang, intervensi berbasis teman sebaya dinilai lebih sesuai. Kesimpulan yang dapat diambil dari penelitian-penelitian ini adalah pentingnya pemahaman yang tepat tentang karakteristik perundungan di konteks budaya tersebut agar dapat dikembangkan intervensi yang efektif sesuai dengan konteks budaya dan karakteristik target.

Perundungan digolongkan menjadi salah satu perilaku agresif dikarenakan adanya aspek kesengajaan di dalamnya (Olweus, 2013). Meskipun perundungan termasuk perilaku agresif, ada beberapa ciri 
khas dari perundungan yang membedakannya dengan perilaku agresif. Ciri-ciri tersebut adalah: adanya aspek pengulangan serta aspek ketidakseimbangan kekuatan antara pelaku dan korban. Oleh karena itu perundungan dapat didefinisikan sebagai tindakan agresif dalam bentuk fisik, verbal ataupun sosialpsikologis, yang secara sengaja direncanakan dan dilakukan oleh seseorang atau sekelompok orang terhadap seseorang atau sekelompok orang, yang memersepsikan bahwa tindakan ini akan berulang dalam jangka waktu yang relatif panjang dan dirinya (atau mereka) tidak berdaya untuk melawan (Djuwita, 2017). Dari definisi ini dapat disimpulkan bahwa perundungan dapat dilakukan oleh pihak yang secara fisik maupun pengaruh sosial lebih kuat dibandingkan korban, dan dapat dilakukan secara berulang.

Secara umum dapat dibedakan dua jenis perundungan, yaitu perundungan tradisional dan perundungan siber (cyber bullying). Yang dimaksud dengan perundungan tradisional secara umum adalah perilaku yang ditujukan untuk merugikan orang lain, secara berulang, dan korban sulit untuk membela diri (Olweus, 1999). Sedangkan perundungan siber secara spesifik adalah tindakan atau perilaku agresif yang dilakukan melalui media elektronik oleh seseorang atau kelompok, secara berulang dan untuk jangka waktu tertentu terhadap korban yang tidak mudah untuk membela diri (Smith dkk., 2008). Dalam perundungan tradisional dapat dibedakan tiga bentuk cara pelaku melakukan perundungan (Olweus, 1993):

a. Bentuk fisik secara langsung, seperti meninju/memukul, menampar dan lain-lain.

b. Bentuk verbal secara langsung, seperti memanggil dengan sebutan yang bisa menyakiti.

c. Bentuk sosial-psikologis secara tidak langsung, seperti perilaku mengucilkan dan menolak orang lain untuk masuk ke dalam suatu kelompok.
Sedangkan perundungan siber terjadi di dunia maya melalui media komunikasi elektronik (Smith dkk., 2008), seperti menggunakan telepon seluler dan sosial media. Misalnya, dengan cara menyebarkan foto atau video mengenai korban yang dapat mempermalukan dan tanpa seijin orang tersebut.

Kejadian perundungan pada umumnya merupakan suatu proses kelompok (O’Connell, Pepler, \& Craig, 1999) karena dalam perundungan ada berbagai peran yang berbeda, yaitu sebagai pelaku, pendukung pelaku, korban, pembela korban, dan orang luar yang tidak terlibat (Sutton \& Smith, 1999). Pelaku adalah pemimpin dalam kejadian perundungan dan pada umumnya secara aktif memberikan inisiatif untuk menerapkan perilaku tersebut, sedangkan korban adalah siswa yang menjadi tujuan perilaku perundungan (Menesini dkk, 2003). Dalam sebagian besar kasus perundungan, kejadian disaksikan oleh sekelompok siswa lain (Hawkins, Pepler, \& Craig, 2001). Salmivalli (2014) mengelompokkan siswa yang menyaksikan kejadian berdasarkan cara mereka merespon ke dalam kategori "participant roles" berikut:

a. Penguat pelaku (reinforcer of the bully), yaitu siswa yang menguatkan perilaku perundungan dalam bentuk verbal maupun nonverbal. Contohnya dengan tertawa atau bersorak saat kejadian perundungan berlangsung. Mereka dapat juga disebutkan sebagai penonton, yaitu siswa yang merasa terhibur oleh kejadian perundungan yang disaksikannya (Naito \& Gielen, 2005).

b. Asisten pelaku (assistant of the bully), yaitu siswa yang secara aktif membantu pelaku, contohnya dengan menangkap korban atau menahan agar korban tidak melarikan diri.

c. Pembela korban (defender of the victim), yaitu siswa yang menunjukkan dukungan terhadap 
korban atau mencoba untuk menghentikan kejadian perundungan. Pembela juga dapat meminta bantuan orang dewasa untuk menghentikan kejadian perundungan (Salmivalli, Lagerspetz, Bjorkqvist, Osterman, \& Kaukiainen, 1996).

d. Orang luar (outsider), yaitu siswa yang menyaksikan kejadian perundungan tanpa melakukan atau mengatakan apa-apa. Mereka dapat juga disebut pendukung diam (silent approvers) dari perundungan, karena sikap diam tersebut dapat diartikan oleh pelaku sebagai bentuk dukungan terhadap perilakunya.

Dalam artikel ini, peneliti membedakan peranan sebagai pelaku, korban, dan saksi. Peranan sebagai penguat pelaku, asisten pelaku, pembela korban, maupun orang luar, dapat dikelompokkan ke dalam kategori yang sama, yaitu saksi perundungan. Dalam beberapa penelitian sebelumnya ditemukan bahwa persentase siswa yang pernah menyaksikan perundungan mencapai angka tertinggi dibandingkan korban dan pelaku. Sebanyak $72 \%$ siswa tingkat SMA mengaku pernah menyaksikan kejadian perundungan (Bradshaw, Sawyer, \& O’Brennan, 2007). Sementara itu dalam penelitian terbaru (Waasdorp, Pas, Zablotsky, \& Bradshaw, 2017), yang melibatkan partisipan siswa kelas 4 hingga 12, menunjukkan hasil bahwa selama 10 tahun terakhir, sebanyak $42,7 \%$ hingga $66,4 \%$ siswa mengaku pernah menjadi saksi perundungan. Data ini menunjukkan bahwa perundungan umumnya terjadi sepengetahuan siswasiswa lain.

Penelitian lain yang membandingkan pola-pola perundungan oleh siswa di negara-negara Inggris dan Jepang menunjukkan perbedaan karakteristik yang signifikan (Kanetsuna, Smith, \& Morita, 2006). Kedua negara tersebut dipilih untuk melihat pengaruh kebudayaan yang berbeda terhadap karakteristik perundungan. Di Inggris, perundungan seringkali dilakukan di taman bermain (playground), oleh satu atau dua siswa yang seangkatan dengan korban, dan berbentuk penyerangan secara langsung. Sedangkan di Jepang, perundungan lebih sering mengambil tempat di dalam ruang kelas, oleh sekelompok teman sekelas korban, dan berbentuk penyerangan secara tidak langsung. Meskipun karakteristik perundungan yang terjadi di kedua negara tersebut berbeda pada bentuk perundungan-di Inggris cenderung fisik dan verbal, sedangkan di Jepang cenderung psikologis (Kanetsuna, Smith, \& Morita, 2006)_, namun demikian, terdapat persamaan yaitu bahwa sebagian besar korban maupun saksi memilih untuk tidak melakukan apa-apa ketika terjadi perundungan. Artinya, para saksi perundungan maupun korban cenderung pasif dan membiarkan perundungan tetap terjadi.

Penelitian tentang perundungan di Indonesia menunjukkan bahwa di kota-kota besar Indonesia, perundungan lebih banyak terjadi di tingkat SMA/SMK (Djuwita \& Royanto, 2008). Pada penelitian lain (Lai, Ye, \& Chang, 2008) yang membandingkan karakteristik dan dampak perundungan di beberapa negara Asia Pasifik, ditemukan bahwa terdapat perbedaan dampak terhadap persepsi anak yang pernah menjadi korban perundungan mengenai sekolahnya di negara-negara tersebut. Misalnya, di Australia, Jepang, dan Singapura, siswa yang belum pernah mengalami perundungan memiliki persepsi yang secara signifikan lebih baik mengenai sekolahnya dibandingkan siswa yang pernah mengalami perundungan. Namun perbedaan yang signifikan tidak nampak pada siswa di Filipina. Dalam penelitian tersebut juga ditemukan bahwa anak-anak di negaranegara Indonesia, Malaysia, dan Singapura enggan ke sekolah dan enggan untuk belajar sebagai akibat dari perundungan yang dialaminya.

Penelitian ini bertujuan untuk memetakan kejadian dan perilaku perundungan yang dilakukan oleh siswa 
tingkat SMA/SMK di Indonesia. Yang akan peneliti petakan adalah pola-pola perundungan yang terjadi di sekolah, seperti peran dari partisipan dalam kejadian perundungan (pelaku, korban, dan saksi), bentuk-bentuk perundungan yang terjadi, serta lokasi dan waktu kejadian. Untuk lebih memahami perilaku setiap peran dalam kejadian perundungan, penelitian ini juga menyelidiki alasan dibalik perilaku perundungan dari sudut pandang pelaku, tindakan yang dilakukan korban saat mengalami perundungan, dan yang dilakukan partisipan saat menyaksikan atau mengetahui adanya kejadian perundungan di sekolahnya, serta alasan partisipan yang pernah menyaksikan memilih untuk untuk tidak melakukan apa-apa. Peneliti juga tertarik untuk mengetahui ada atau tidaknya perbedaan yang signifikan pada persepsi tentang sekolah, antara partisipan yang pernah berperan dalam perundungan dengan yang tidak pernah.

\section{METODE PENELITIAN}

Penelitian ini dilakukan terhadap 138 partisipan yang merupakan mahasiswa dan mahasiswi tingkat pertama yang berasal dari SMA/SMK di Indonesia. Alasan dari pemilihan mahasiswa tingkat pertama

Tabel 1. Karakteristik Partisipan Penelitian

\begin{tabular}{|c|c|}
\hline Karakteristik Partisipan & Total Sampel $(N=138)$ \\
\hline \multicolumn{2}{|l|}{ Gender } \\
\hline Laki-laki & 41 \\
\hline Perempuan & 97 \\
\hline \multicolumn{2}{|l|}{ Usia } \\
\hline $17-19$ & 119 \\
\hline $20-22$ & 18 \\
\hline $23-25$ & 1 \\
\hline \multicolumn{2}{|l|}{ Asal Provinsi } \\
\hline Aceh & 1 \\
\hline Bali & 1 \\
\hline Bangka-Belitung & 1 \\
\hline Banten & 11 \\
\hline Bengkulu & 1 \\
\hline DKI Jakarta & 36 \\
\hline Jambi & 1 \\
\hline Jawa Barat & 21 \\
\hline Jawa Tengah & 2 \\
\hline Jawa Timur & 15 \\
\hline Kalimantan Selatan & 1 \\
\hline Kalimantan Timur & 1 \\
\hline Riau & 7 \\
\hline Sulawesi Selatan & 1 \\
\hline Sumatera Barat & 5 \\
\hline Sumatera Utara & 33 \\
\hline \multicolumn{2}{|l|}{ Jenis SMA } \\
\hline SMA Negeri & 74 \\
\hline SMA Swasta & 44 \\
\hline SMK Negeri & 8 \\
\hline SMK Swasta & 5 \\
\hline Madrasah & 7 \\
\hline \multicolumn{2}{|l|}{ Tahun Lulus SMA } \\
\hline 2016 & 36 \\
\hline 2017 & 102 \\
\hline
\end{tabular}


adalah karena perundungan merupakan isu yang dianggap peka, sehingga kemungkinan partisipan yang berstatus siswa tidak berani mengungkapkan secara terbuka pandangan mereka tentang perundungan. Partisipan diminta untuk mengingat dan menceritakan kembali pengalamannya terkait perundungan selama di tingkat SMA. Partisipan penelitian diperoleh dari 22 universitas di Pulau Jawa dan Sumatera, dan terdiri dari 41 laki-laki dan 97 perempuan.

Dalam penelitian ini pengambilan sampel dilakukan menggunakan teknik convenience sampling (Gravetter \& Forzano, 2012), yaitu pemilihan sampel tanpa ditetapkan terlebih dahulu, melainkan diperoleh secara kebetulan dan apabila dianggap dapat menjadi sumber data. Peneliti juga menggunakan teknik snowballing (Browne, 2005) dalam proses pengambilan sampel, yaitu teknik pemilihan sampel yang diawali dari jumlah kecil dan menjadi semakin membesar dengan cara meminta sampel awal untuk mengajak orang-orang lain yang dipilihnya. Banyaknya sampel yang diperoleh disesuaikan dengan kebutuhan peneliti.

Pengambilan data dilakukan dengan menggunakan kuesioner "Survei Pengalaman Interaksi Sosial di Sekolah". Kuesioner diisi secara online, dengan cara peneliti terlebih dahulu memberikan tautan pengisian kuesioner kepada partisipan. Pertanyaan-pertanyaan dalam kuesioner ini diawali dari persepsi mahasiswa mengenai pengalaman bersekolah di SMA/SMK asalnya, dan kemudian dilanjutkan ke pertanyaan-pertanyaan mengenai perundungan. Analisa data kemudian dilakukan dengan menggunakan analisis statistik deskriptif dan uji perbandingan $t$ test untuk persepsi terhadap sekolah antara siswa yang pernah berperan dalam perundungan dengan siswa yang tidak pernah.

\section{ANALISIS \& HASIL}

Hasil penelitian ini menggambarkan pengalaman perundungan yang terjadi di tingkat SMA. Berdasarkan hasil dari kuesioner, hal pertama yang ditemukan oleh peneliti adalah bahwa perundungan benarbenar terjadi di sekolah, khususnya di tingkat SMA. Hal tersebut dapat disimpulkan dengan melihat bahwa dari total 138 subyek, sebanyak $71 \%$ mengaku pernah menjadi korban, pelaku, atau saksi dalam kejadian perundungan di sekolahnya. $71 \%$ partisipan tersebut berasal dari 94 SMA yang berbeda, sehingga dapat dikatakan bahwa perundungan terjadi pada $75,8 \%$ SMA yang merupakan asal sekolah partisipan.

Gambar 1 menunjukkan bahwa sebanyak $29 \%$ partisipan menyatakan bahwa di sekolah asal mereka tidak pernah terjadi perundungan. Sementara sebagian besar dari partisipan, dengan persentase $69,6 \%$, pernah menyaksikan atau mengetahui adanya kejadian perundungan di sekolah. Sebanyak $34,1 \%$ pernah menjadi korban perundungan, sedangkan $18,8 \%$ partisipan mengakui pernah menjadi pelaku perundungan di sekolahnya. Total dari persentase yang diperoleh melebihi $100 \%$ dikarenakan siswa yang pernah menjadi korban mungkin juga memiliki pengalaman sebagai saksi atau juga menjadi pelaku.

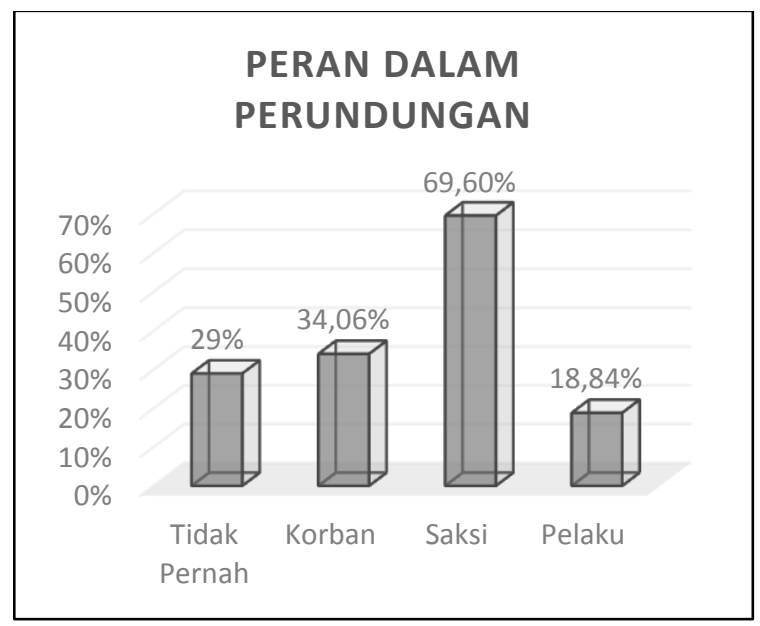

Gambar 1. Peran dalam perundungan.

Untuk mengetahui bentuk-bentuk perundungan yang banyak terjadi di tingkat SMA, peneliti mengkhususkan satu pertanyaan untuk tujuan tersebut. 
Pertanyaan ditujukan bagi subyek yang mengaku pernah menjadi korban perundungan. Hasil pada Gambar 2 menunjukkan bahwa persentase tertinggi yaitu $35,1 \%$ terdapat pada bentuk verbal, seperti diolok-olok, dipermalukan, dan lainlain. Bentuk dengan persentase tertinggi kedua yaitu sebanyak $26,3 \%$ adalah bentuk sosial, seperti dikucilkan, dipermalukan di depan orang lain, dan lain-lain.

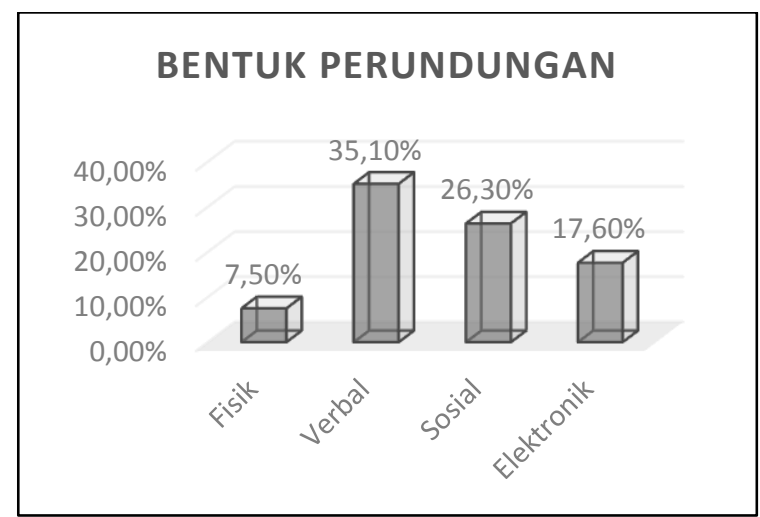

Gambar 2. Bentuk perundungan

Bentuk-bentuk perundungan tersebut terjadi di lokasi-lokasi tertentu. Pada Gambar 3 dapat dilihat lokasi yang paling sering menjadi tempat kejadian perundungan. Lokasi yang paling sering menjadi tempat kejadian perundungan adalah di dalam kelas $(63,1 \%)$. Lokasi dengan persentase tertinggi kedua adalah tempat lain di luar sekolah, yaitu sebesar $53,6 \%$. Sedangkan beberapa lokasi lainnya yang cukup banyak dilaporkan sebagai tempat kejadian perundungan adalah lorong sekolah, toilet sekolah, dan kantin sekolah.

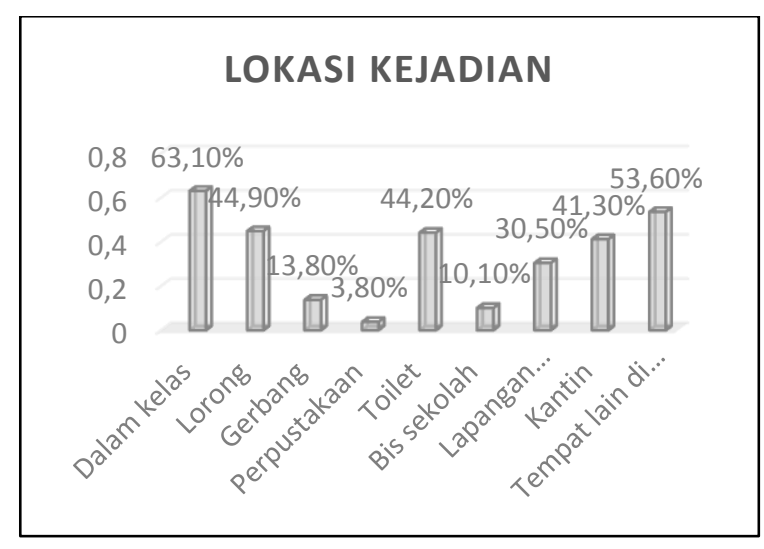

Gambar 3. Lokasi kejadian perundungan.
Peneliti juga menemukan bahwa kejadian perundungan terjadi pada waktuwaktu tertentu. Gambar 4 menunjukkan partisipan melaporkan bahwa perundungan paling sering terjadi saat jam istirahat (64,5\%), 63,8\% partisipan melaporkan bahwa perundungan juga sering terjadi setelah jam sekolah. Saat mengikuti kegiatan lain dari sekolah (contoh: kegiatan ekstrakulikuler) dan saat pergantian jam pelajaran menjadi waktu kejadian terbanyak ketiga dan keempat, dimana masing-masing mencapai persentase $44,1 \%$ dan $41,3 \%$.

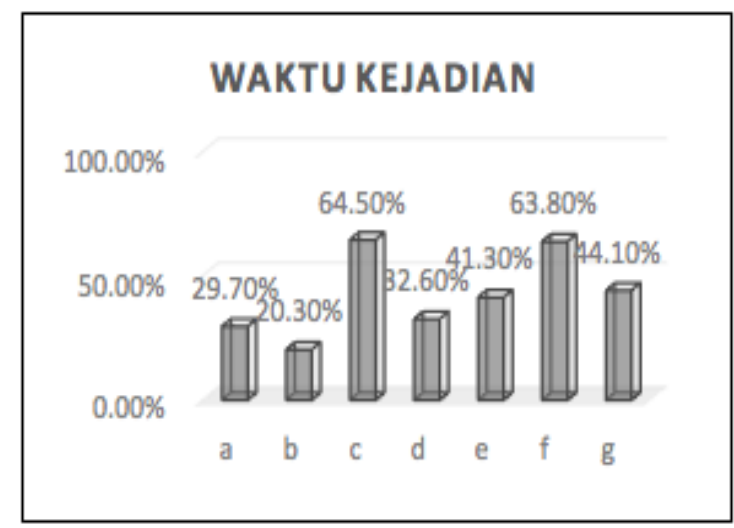
a. Di perjalanan menuju ke atau kembali dari sekolah
b. Sebelum jam sekolah
c. Jam istirahat
d. Selama jam pelajaran
e. Pergantian jam pelajaran
f. Setelah jam sekolah
g. Kegiatan lain dari sekolah

Gambar 4. Waktu kejadian perundungan

Empat alasan tertinggi dari partisipan yang mengaku pernah melakukan perundungan adalah karena perilaku korban yang dinilai aneh, seperti sering nyolot atau cari perhatian $(50 \%)$, karena iseng $(39,3 \%)$, balas dendam $(23,2 \%)$ dan karena pelaku menganggap bahwa korban yang mengalami perundungan akan memiliki kepribadian yang lebih kuat $(23,2 \%)$. Pada 
Gambar 5 dapat dibaca berbagai alasan yang diberikan siswa pelaku perundungan.

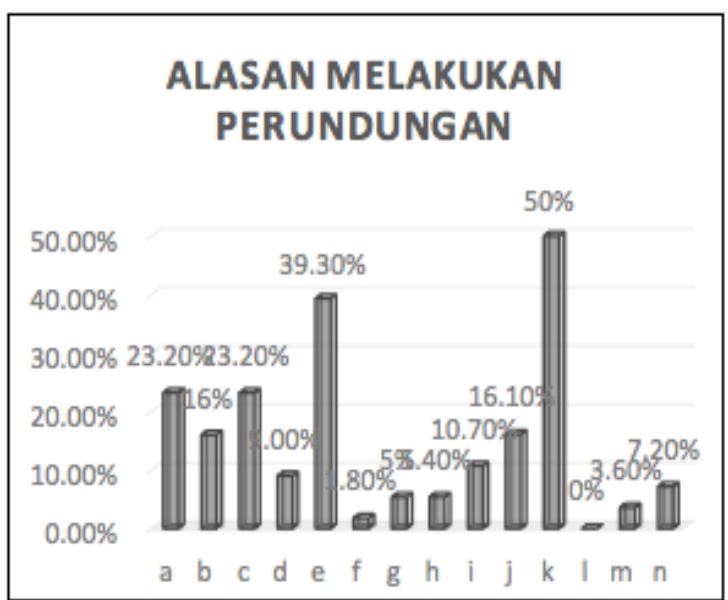

$$
\begin{aligned}
& \text { a. Balas dendam } \\
& \text { b. Tradisi sekolah } \\
& \text { c. Menguatkan kepribadian mereka } \\
& \text { d. Menanamkan nilai-nilai sekolah } \\
& \text { e. Iseng } \\
& \text { f. Gender } \\
& \text { g. Ras, budaya/warna kulit } \\
& \text { h. Latar belakang asal daerah } \\
& \text { i. Nilai akademis } \\
& \text { j. Penampilan yang berbeda dengan yang } \\
& \text { lain } \\
& \text { k. Perilaku aneh, suka nyolot, cari perhatian } \\
& \text { l. Agama } \\
& \text { m. Keadaan ekonomi } \\
& \text { n. Disabilitas }
\end{aligned}
$$

Gambar 5. Alasan melakukan perundungan.

Selanjutnya, peneliti juga ingin mengetahui apa saja yang pernah dilakukan oleh partisipan yang penah menjadi korban sebagai respon dari kejadian perundungan yang dialaminya. Dalam kuesioner, peneliti memberikan beberapa bentuk tindakan sebagai opsi bagi partisipan. Hasil yang tertera pada Gambar 6 menunjukkan bahwa sebanyak $54,5 \%$ partisipan memilih untuk mengabaikan kejadian perundungan yang dialaminya, sedangkan $37,3 \%$ menyatakan memilih untuk melawan pelaku atau membela diri.

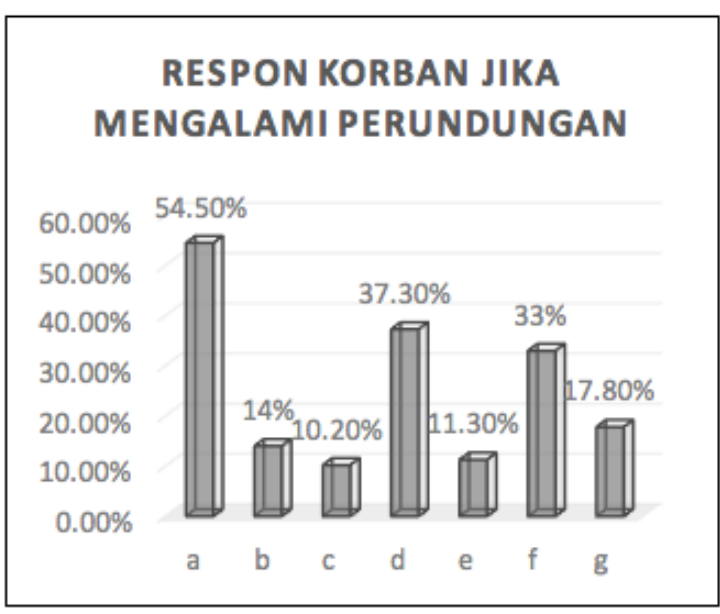

a. Mengabaikan
b. Memberitahu orang tua
c. Memberitahu guru
d. Melawan pelaku/membela diri
e. Meminta bantuan orang lain
f. Membuat lelucon
g. Membalas dendam

Gambar 6. Respon korban jika mengalami perundungan

Peneliti ingin mengetahui apa yang menjadi respon dari para partisipan yang pernah menyaksikan atau mengetahui adanya kejadian perundungan. Gambar 7 menunjukkan bahwa sebagian besar partisipan $(69,6 \%)$ pernah memilih untuk menolong korban setelah kejadian secara tidak langsung yaitu dengan memberikan dukungan emosional misalnya dengan menyemangatinya atau menemaninya. Sebanyak $55,1 \%$ partisipan menjawab bahwa mereka akan berani menolong korban secara langsung (membela korban), dan $53,6 \%$ menyatakan akan mencari bantuan orang dewasa seperti guru atau siswa lain $(55,1 \%)$. Jika saksi siswa tidak menolong korban secara langsung ataupun tidak langsung, sebanyak $57,3 \%$ juga mengaku pernah hanya menonton saja tanpa melakukan apa-apa atau mereka cenderung memilih untuk meninggalkan lokasi (55,8\%). Sebanyak 39\% partisipan mengaku akan mengganggap kejadian perundungan sebagai hiburan. Perundungan juga dapat memunculkan perlakuan agresi 
dari saksi, karena 37\% saksi mengatakan bahwa mereka akan membalas pelaku.

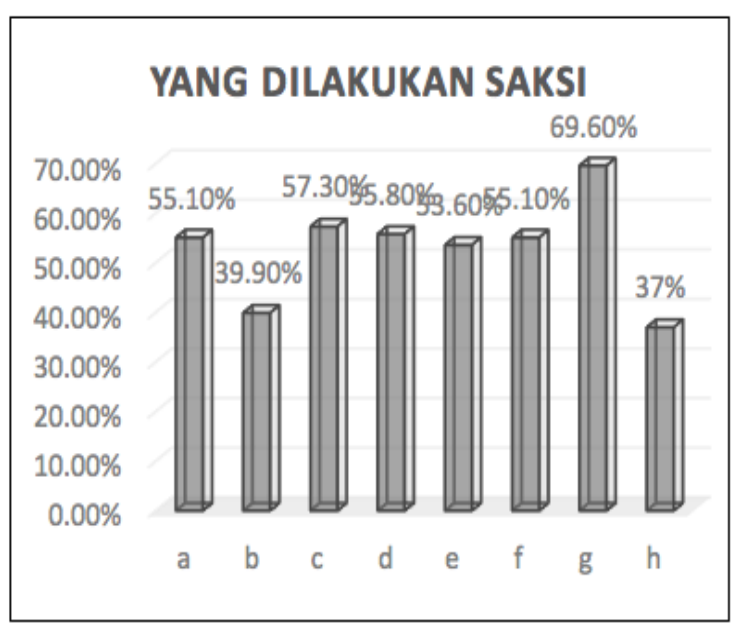
a. Membela korban
b. Menertawakan
c. Menonton dengan diam
d. Pergi
e. Melapor ke orang dewasa
f. Mencari bantuan siswa lain
g. Mendukung korban setelah kejadian
h. Membalas pelaku

Gambar 7. Yang dilakukan saksi saat terjadi perundungan.

Jadi dari data-data pada Gambar 7 diketahui bahwa sebagian besar partisipan mengaku memilih untuk tidak melakukan apa-apa atau tidak menolong korban perundungan, baik dengan cara pergi meninggalkan lokasi atau menonton dengan diam atau bahkan menikmati kejadian sebagai hiburan yang membuat tertawa. Bagi partisipan yang termasuk dalam kategori tersebut, peneliti menanyakan mengenai alasan apa saja yang pernah mendorong mereka untuk tidak melakukan apa-apa. Gambar 8 menunjukkan hasil bahwa mereka tidak ingin terlibat $(61,4 \%)$, tidak tahu apa yang harus dilakukan $(61,3 \%)$, dan merasa siswa lain juga tidak akan melakukan apa-apa $(60,4 \%)$. Hanya $10,4 \%$ yang menyatakan tidak melakukan apa-apa karena menganggap perundungan adalah hal yang wajar.

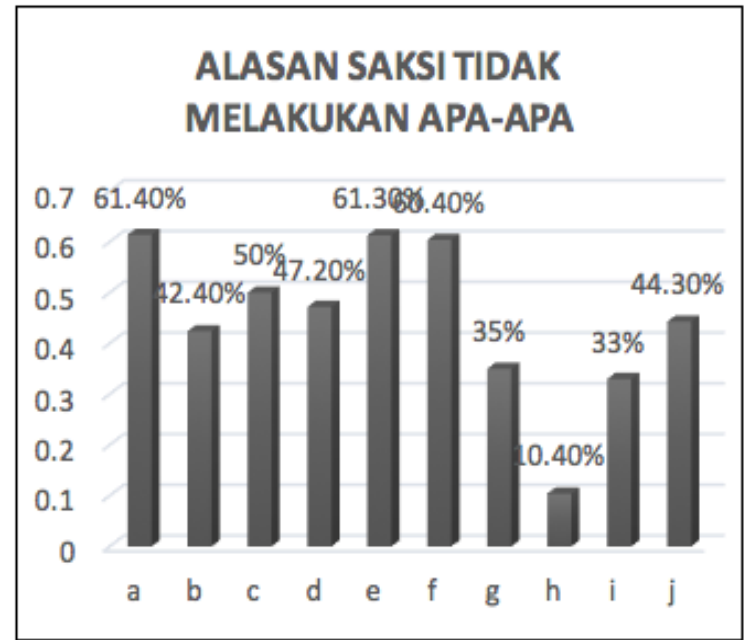
a. Tidak Ingin Terlibat
b. Takut menjadi korban
c. Takut korban akan diperlakuki Vertical (Value) Ax parah
d. Tidak mau dianggap sok pahlawan
e. Tidak tahu apa yang harus dilakukan
f. Siswa lain juga tidak melakukan apa-apa
g. Guru/orang dewasa di sekolah juga tidak melakukan apa-apa
h. Merasa perundungan adalah hal wajar
i. Merasa bukan urusan saya
j. Tidak merasa keterlibatan akan membawa perubahan

Gambar 8. Alasan saksi tidak melakukan apa-apa.

Meskipun perundungan terbukti terjadi di sekolah, secara keseluruhan para partisipan memiliki persepsi yang positif mengenai SMA asalnya. Seperti pada Gambar 9 yang menunjukkan sebanyak 91,7\% partisipan merasa diterima oleh siswa dan orang dewasa di sekolah dan 90,6\% mengaku merasa senang di sekolah. Hanya sebagian kecil data yang menunjukkan persepsi negatif, seperti $12,35 \%$ subyek yang tidak merasa gedung sekolah adalah tempat yang nyaman untuk belajar dan $11,5 \%$ yang tidak merasa memperoleh bantuan apabila dibutuhkan. 
Gambar 9. Persepsi Tentang Sekolah

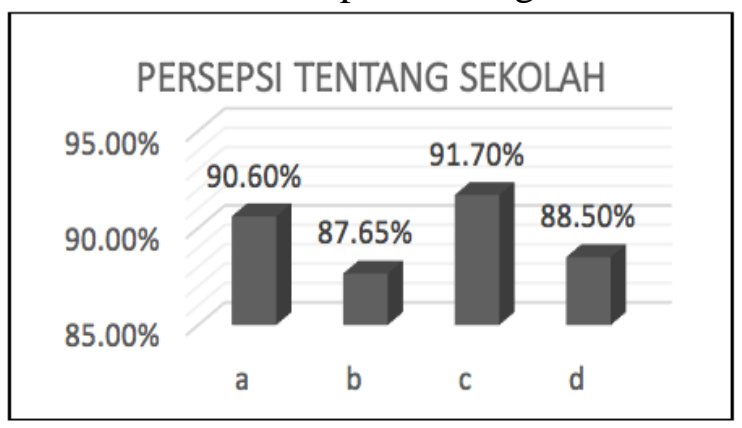

a. Senang di sekolah

b. Gedung sekolah adalah tempat nyaman untuk belajar

c. Merasa diterima oleh siswa dan orang dewasa di sekolah

d. Memperoleh bantuan apabila dibutuhkan

Untuk memperoleh gambaran yang lebih detail mengenai persepsi para subyek terhadap sekolahnya, peneliti melakukan uji t-test untuk membandingkan persepsi partisipan yang pernah menjadi korban, saksi yang tidak terlibat, atau pelaku dan pendukung pelaku (Ya), dengan subyek yang belum pernah (Tidak). Rata-rata nilai persepsi partisipan yang pernah menjadi korban, saksi, maupun pelaku perundungan menunjukkan angka 4,702 hingga 4,779 dengan angka 6 sebagai skor persepsi terbaik. Hasil pada Tabel 2 menunjukkan bahwa secara rata-rata, partisipan yang belum pernah menjadi korban memiliki persepsi yang lebih baik, yaitu sebesar $M=$ 5,031 dibandingkan partisipan yang pernah menjadi korban $(M=4,702)$. Perbedaan persepsi ini signifikan dengan $p<0,05$.
Persepsi yang secara signifikan lebih baik juga nampak pada partisipan yang belum pernah menjadi saksi atau pelaku dan pendukung, dibandingkan partisipan yang belum pernah menjadi saksi atau pelaku dan pendukung.

\section{DISKUSI}

Berdasarkan hasil dari penelitian ini ditemukan bahwa sebagian besar mahasiswa Indonesia yang menjadi partisipan mengingat bahwa perundungan pernah terjadi di SMA/SMK asalnya. Konsisten dengan penelitian-penelitian terdahulu, perundungan di SMA masih sering terjadi. Bentuk perundungan yang paling sering terjadi adalah perundungan verbal disusul dengan perundungan berbentuk sosial seperti pengucilan dan fitnah, serta berbentuk elektronik. Hal ini sejalan dengan penelitian-penelitian sebelumnya (Djuwita \& Royanto, 2008) yang menunjukkan bahwa pada siswa SMA bentuk perundungannya ke arah bentukbentuk non fisik.

Analisis mengenai perilaku partisipan berdasarkan peran yang pernah dimiliki dalam kejadian perundungan di sekolah juga menghasilkan temuan yang menarik mengenai pelaku. Para partisipan yang mengaku pernah melakukan perundungan di SMA/SMK beralasan bahwa perilaku agresi mereka dipicu oleh perilaku korban yang dianggap aneh. Sebagian lainnya juga mengaku hanya melakukan perundungan karena iseng. Pada penelitian-penelitian

Tabel 2. Uji Perbandingan T-Test Untuk Persepsi Tentang Sekolah Antara Pernah dan Tidak Pernah Menjadi Korban, Saksi Tidak Terlibat, atau Pelaku dan Pendukung

\begin{tabular}{lccccccc}
\hline & & \multicolumn{2}{c}{ Korban } & \multicolumn{2}{c}{$\begin{array}{c}\text { Saksi Tidak } \\
\text { Terlibat }\end{array}$} & \multicolumn{2}{c}{$\begin{array}{c}\text { Pelaku dan } \\
\text { Pendukung }\end{array}$} \\
& & Tidak & Ya & Tidak & Ya & Tidak & Ya \\
\hline $\begin{array}{l}\text { Persepsi } \\
\text { tentang }\end{array}$ & Mean & 5.031 & 4.702 & 5.023 & 4.779 & 4.957 & 4.564 \\
sekolah & SD & 0.625 & 0.71 & 0.582 & 0.79 & 0.642 & 0.761 \\
& $\mathrm{df} / \mathrm{t}(\mathrm{p})$ & 88.476 & $2.4^{*}$ & 88.391 & $2.035^{*}$ & 42.906 & $2.76^{* *}$ \\
\hline
\end{tabular}

${ }^{*} p<0.05,{ }^{* *} p<0.01$ 
terdahulu, ditemukan juga bahwa di Indonesia perundungan sering dilakukan oleh kelompok senior terhadap junior, baik secara perorangan maupun berkelompok (Djuwita \& Royanto, 2008; Riauskina, Djuwita, \& Soesetio, 2005). Namun hal ini tidak ditanyakan oleh peneliti kepada partisipan, sehingga menjadi salah satu keterbatasan dari penelitian ini.

Selain itu, di sisi saksi perundungan, penelitian ini mengemukakan hasil bahwa hanya sebagian kecil partisipan menganggap perundungan sebagai hal yang wajar. Hasil ini menandakan adanya kesadaran sebagian besar partisipan mengenai buruknya perundungan.

Hasil penelitian ini sejalan dengan penelitian yang dilakukan oleh Lai, Ye, dan Chang (2008), yaitu bahwa partisipan di Australia, Jepang, dan Singapura yang belum pernah mengalami perundungan akan memiliki persepsi yang lebih positif tentang sekolahnya dibandingkan dengan siswa yang pernah mengalami perundungan. Hasil uji t-test dalam penelitian ini menunjukkan persepsi yang lebih baik mengenai sekolah pada partisipan yang belum pernah menjadi korban, saksi, maupun pelaku perundungan di sekolah. Namun, secara keseluruhan, partisipan dalam penelitian ini tidak menunjukkan persepsi yang buruk mengenai sekolah sebagai akibat dari pengalaman perundungan.

\section{SIMPULAN}

Sebagian besar perundungan berbentuk verbal $(35,1 \%)$, terjadi di dalam kelas $(63,1 \%)$, dan pada jam istirahat $(64,5 \%)$. Partisipan yang pernah menjadi pelaku perundungan $(18,8 \%)$ menyalahkan perilaku aneh korban sebagai penyebab utama perundungan. Dari $34,1 \%$ partisipan yang pernah menjadi korban, sebagian besar memilih untuk mengabaikan kejadian. Sementara dari $69,6 \%$ partisipan yang pernah menjadi saksi perundungan, sebagian besar memilih untuk tidak melakukan apa-apa karena tidak ingin terlibat.

\section{SARAN}

Untuk mendapatkan gambaran perundungan di Indonesia secara lebih menyeluruh dan mendalam, disarankan untuk melibatkan partisipan dalam jumlah yang lebih besar dan mencakup lebih banyak provinsi di Indonesia.

Hasil penelitian juga menunjukkan pentingnya dilakukan intervensi pencegahan perundungan di SMA. Idealnya siswa SMA bersama pihak sekolah maupun orang tua bekerja sama untuk menghilangkan perundungan di sekolah dengan cara merubah budaya sekolah menjadi sekolah yang ramah dan penuh kepedulian pro-sosial.

\section{DAFTAR PUSTAKA}

Bradshaw, C. P., Sawyer, A. L., \& O'Brennan, L. M. (2007). Bullying and peer victimization at school: Perceptual differences between students and school staff. School Psychology Review, 36, 361382.

Browne, K. (2005). Snowball sampling: Using social networks to research nonheterosexual women. International Journal of Social Research Methodology: Theory \& Practice, 8(1), 47-60. http://dx.doi.org/10.1080/13645570320000 81663

Cowie, H. (2014). Understanding the role of bystanders and peer support in school bullying. International Journal of Emotional Education, 6(1), 26-32.

Craig, W., Harel-Fisch, Y., Fogel-Grinvald, H., Dostaler, S., Hetland, J., Simons-Morton, B., . . . Group, H. B. W. (2009). A crossnational profile of bullying and victimization among adolescents in 40 countries. Int J Public Health, 54 Suppl 2, 216-224. doi:10.1007/s00038-009-5413-9

Djuwita, R. (2017). Dilema saksi perundungan: membela korban atau mendukung pelaku? Peranan orientasi nilai, kebahagiaan psikologis, dan keyakinan efikasi dalam perilaku menolong saksi perundungan (Disertasi). Universitas Indonesia, Depok. 
Djuwita, R., \& Royanto, L. R. M. (2008). Peranan faktor personal dan situasional terhadap perilaku bullying di tiga kota besar di Indonesia. Unpublished manuscript. Fakultas Psikologi Universitas Indonesia, Depok, Indonesia.

Gini, G., \& Pozzoli, T. (2009). Association between bullying and psychosomatic problems: A meta-analysis. Pediatrics, 123, 1059-1065. doi: 10.1542/peds.200812

Gastic, B. (2008). School truancy and the disciplinary problems of bullying victims. Educational Review, 60(4), 391-404. Doi.org/10.1080/00131910802393423

Gravetter, F. J., \& Forzano, L. B. (2012). Research methods for the behavioral sciences $\left(4^{\text {th }}\right.$ Edition). Wadworth: Cengage Learning.

Hawker, D. S. J., \& Boulton, M. J. (2000). Twenty years' research on peer victimization and psychosocial maladjustment: A meta-analytic review of cross-sectional studies. Journal of Child Psychology and Psychiatry and Allied Disciplines, 41, 441-455. doi: 10.1111/1469-7610.00629

Hawkins, D. L., Pepler, D. J., \& Craig, W. M. (2001). Naturalistic observations of peer interventions in bullying. Social Development, $\quad 10, \quad 512-527$. http://dx.doi.org/10.1111/1467-9507.00178

Hernández, T. J., \& Seem, S. R. (2004). A safe school climate: A systemic approach and the school counselor. Professional School Counseling, 7(4), 256-262.

Juvonen, J., Wang, Y., \& Espinoza, G. (2011). Bullying experiences and compromised academic performance across middle school grades. The Journal of Early Adolescence, 31(1), 152-173. https://doi.org/10.1177/027243161037941 5

Kanetsuna, T., Smith, P. K., \& Morita, Y. (2006). Coping with bullying at school: Children's recommended strategies and attitudes to school-based interventions in england and japan. Aggressive Behavior, 32, 570-580.

Lai, S. L., Ye, R., \& Chang, K. P. (2008). Bullying in middle schools: An asianpacific regional study. Asia Pacific Education Review, 9(4), 503-515. https://doi.org/10.1007/BF03025666
Menesini, E., Codecasa, E., Benelli, B., \& Cowie, H. (2003). Enhancing children's responsibility to take action against bullying: Evaluation of a befriending intervention in italian middle schools. Aggressive Behavior, 29, 1-14.

Morrison, BE. (2002). Bullying and victimisation in schools: A restorative justice approach, Trends and Issues in Crime and Criminal Justice, 219, 1-6.

Naito, T., \& Gielen, U. P. (2005). Bullying and ijime in japanese schools. Retrieved from https://www.researchgate.net/publication /226147844_Bullying_and_ljime_in_Japan ese_Schools.

O'Connell, P., Pepler, D., \& Craig, W. (1999). Peer involvement in bullying: Insights and challenges for intervention. Journal of Adolescence, 22, 437-452. doi: 10.1006/jado.1999.0238

Olweus, D. (1993). Bullying at school: What we know and what we can do. Oxford: Blackwell.

Olweus, D. (1999). Dalam P. K. Smith, Y. Morita, J. Junger-Tas, D. Olweus, R. Catalano, \& P. Slee (Eds.), The nature of school bullying: A cross-national perspective. London \& New York: Routledge.

Pečjak, S., \& Pirc, T. (2017). School climate in peer bullying: observers' and active participants' perceptions. Horizons of Psychology, 26, 74-82. doi:10.20419/2017.26.470

Riauskina, I. I., Djuwita, R., \& Soesetio, S. R. (2005). "Gencet-gencetan" di mata siswa/siswi kelas 1 SMA: Naskah kognitif tentang arti, skenario, dan dampak "gencet-gencetan". Jurnal Psikologi Sosial, 12(01), 1-13.

Salmivalli, C., Lagerspetz, K., Bjorkqvist, K., Osterman, K., \& Kaukiainen, A. (1996). Bullying as a group process: Participant roles and their relations to social status within the group. Aggressive Behavior, 22, 1-15. doi: 10.1002/(SICI)10982337(1996)22:1<1 ::AID-AB1>3.0.CO;2$\mathrm{T}$

Smith, P. K., Cowie, H., Olafsson, R. F., \& Liefooghe, A. P. D. (2002). Definitions of bullying: A comparison of terms used, and age and gender differences, in a fourteencountry international comparison. Child Development, 73(4), 1119-1133. doi:10.1111/1467-8624.00461 
Smith, P.K., Mahdavi, J., Carvalho, M., Fisher, S., Russell, S., Tippett, N. (2008). Cyberbullying: Its nature and impact in secondary schools. J. Child Psychol. Psychiatry, 49, 376-85. doi: 10.1111/j.1469-7610.2007.01846.x.

Thornberg, R., Tenenbaum, L., Varjas, K., Meyers, J., Jungert, T., \& Vanegas, G. (2012). Bystander motivation in bullying incidents: To intervene or not to intervene?. Western Journal of Emergency Medicine, 13(3), 247-252. doi: 10.5811/westjem.2012.3.11792

Tsang, S. K., Hui, E. K., \& Law, B. (2011). Bystander position taking in school bullying: The role of positive identity, selfefficacy, and self-determination. The Scientific World Journal, 11, 2278-2286. http://dx.doi.org/10.1100/2011/531474

Vanderbilt, D., \& Augustyn, M. (2010). The effects of bullying. Paediatrics and Child Health, 20(7), 315-320. https://doi.org/10.1016/j.paed.2010.03.008

Waasdorp, T. E., Pas, E. T., Zablotsky, B., \& Bradshaw, C. P. (2017). Ten-year trends in bullying and related attitudes among 4thto 12 th graders. Pediatrics, 139(6), 1-8. doi:10.1542/peds.2016-2615

Wolke, D., Copeland, W. E., Angold, A., \& Costello, E. J. (2013). Impact of bullying in childhood on adult health, wealth, crime, and social outcomes. Psychological Science, 24(10), 1958-1970. https://doi.org/10.1177/095679761348160 8 